\title{
Correlation between Autorefractometry and Retinoscopy with Subjective Refraction in Refractive Error Patients at Dr Kariadi Hospital, Semarang
}

\author{
Disti Hardiyanti ${ }^{1}$, Fatimah Dyah $\mathbf{N A}^{2}$ \\ ${ }^{1}$ Resident of Ophthalmology Departemen of Diponegoro University, Kariadi Hospital, Semarang, Central java \\ ${ }^{2}$ Staff of Refraction and contact lens division, Ophthalmology Department of Diponegoro University, Kariadi \\ Hospital, Semarang, Central Java \\ E-mail: distihardiyanti19121991@gmail.com
}

\begin{abstract}
Objective: Refractive errors are a major cause of visual impairment in Indonesia. In Dr. Kariadi Hospital Semarang, it is amongst the top five diagnoses within the ophthalmology department. Therefore, objective refraction is imperative for the management of refractive errors. These examinations include autorefractometry and retinoscopy. Despite the fact that retinoscopy is the gold standard, autorefractometry is more desirable as it is more sophisticated, swift, and convenient. Autorefractometry's results are expected to match results from subjective correction, therefore, reduce examination time as patient visits increase. This study aims to determine the correlation between autorefractometry and retinoscopy examination with subjective refraction.

Methods: The study design was cross-sectional. The study was conducted on 34 eyes with refractive error taken by consecutive sampling. The subjects had to meet inclusion and exclusion criteria. All subjects underwent visual acuity examination, refractive correction by autorefractometry, retinoscopy, and subjective refraction. All data were processed by using computerized formulations.

Results: Based on the demographics there were $61.8 \%$ of women and $38.2 \%$ of men with an average age of $29.7+9$. The results of this study showed a strong correlation between autorefractometry and subjective refraction. Furthermore, retinoscopy shows a strong correlation with subjective refraction as well.
\end{abstract}

Conclusion: This study shows retinoscopy is superior to autorefractometry. However, autorefractometry is a viable replacement for patients in Dr. Kariadi Hospital Semarang.

Keywords: Autorefractometry, retinoscopy, subjective refraction.

\begin{abstract}
ABSTRAK
Tujuan : Kelainan refraksi merupakan penyebab utama gangguan penglihatan di Indonesia dan termasuk dalam lima besar diagnosis utama pada kunjungan pasien di poli mata RS DR Kariadi semarang, sehingga memerlukan pemeriksaan refraksi objektif yang efektif dan efisien. Pemeriksaan refraktif objektif tersebut yaitu autorefraktometri dan retinoskopi. Meskipun Autorefraktometri tidak merupakan baku emas seperti retinometri namun autorefraktometri lebih diminati karena dianggap canggih, cepat dan nyaman. Hasil autorefraktometri diharapkan dapat mendekati hasil koreksi subjektif sehingga mempercepat pemeriksaan di Poli dengan kunjungan pasien yang terus meningkat. Penelitian
\end{abstract}


ini bertujuan untuk mengetahui korelasi pemeriksaan kelainan refraksi dengan menggunakan autorefraktometri dan retinoskopi terhadap pemeriksaan refraksi subjektif.

Metodelogi: Desain penelitian adalah crossectional. Penelitian dilakukan pada 34 mata dengan kelainan refraksi yang diambil secara consecutive sampling dengan memenuhi kriteria inklusi dan ekslusi. Seluruh subjek penelitian dilakukan pemeriksaan visus dasar,visus koreksi dari hasil autorefraktometri, retinoskopi, dan refraksi subjektif. Seluruh data diolah melalui tahapan pengumpulan, pengkodean, penginputan dan pengolahan data menggunakan frekuensi, mean, standart deviasi dan uji korelasi regresi menggunakan formulasi komputerisasi.

Hasil: Berdasarkan data demografi didapatkan perempuan 61.8\% dan laki-laki 38.2\% dengan usia ratarata 29.7 \pm 9 . Data korelasi didapatkan baik pemeriksaan retinometri maupun autorefraktometri keduanya efektif dan memiliki hubungan yang sangat kuat jika dibandingkan dengan pemeriksaan refraksi subjektif $(\mathrm{r}=0.997(\mathrm{p}<0.0000)$ dengan $\mathrm{y}=0.137+0.998 \mathrm{x}, \mathrm{r}=0.995(\mathrm{p}<0000)$ dengan $\mathrm{y}=-$ $0.249+0.984 x$,

Kesimpulan: Pada penelitian ini didapatkan meskipun pemeriksaan retinoskopi lebih unggul dibandingkan autorefraktometri, namun autorefraktometri dapat menggantikan pemeriksaan retinoskopi pada pasien kelainan refraksi di RSDK Semarang.

Kata kunci: Autorefraktometri, retinoskopi, refraksi subjektif

\section{INTRODUCTION}

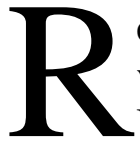

efractive errors are a major cause visual impairment in the world. Uncorrected refractive errors reaches up to $43 \%$ amongst all visual impairment. In Indonesia, refractive errors is the main cause of global blindness following cataracts. Uncorrected refractive errors reach up to $43 \%$ among all visual impairments. In Indonesia, refractive errors are the main causes of ophthalmic disorders with increasing prevalence each year. In 2012 , an estimated $25 \%$ of the population or 55 million lives of the Indonesian people suffers from refractive errors. ${ }^{1,2,3}$

Refractive errors may be troubling for school-aged children and have socioeconomic consequences. Thus, it has been a concern for the Indonesian government in the prevention of refractive errors. Accurate measurement of refractive errors is required for the satisfactory correction and vision improvement. Several methods for measuring refractive errors have been introduced in the clinic over the year, including subjective refraction, retinoscopy, autorefractometry. ${ }^{4,5,6,7}$

In Dr. Kariadi Hospital Semarang (RSDK), refractive errors are amongst the five most diagnosed diseases in outpatient visits. The increasing number of outpatients demands an effective and efficient objective refraction examination.

Retinoscopy (RE) and subjective refraction (SR) are the gold standards for refraction examination. Unfortunately, with recent technology in the ophthalmologic examination, retinoscopy has been overlooked. Retinoscopy examination also has other drawbacks including a dilated pupil which requires time, inconvenience for the patient after examination, and it is operator dependent. ${ }^{8,9}$

Autorefractometer (AR) has become the main choice in health centers with numerous outpatients. Being an automatic device, autorefractometer requires less examination time and reduces potential operator errors. However, results from AR alone cannot be used for prescribing spectacles. Conversely, subjective refraction without objective corrections requires too much time. Therefore, a suitable result between the two may assist in refraction correction..$^{8,9}$

\section{MTHODS}

\section{Study design}

This study is cross-sectional with consecutive sampling. Thirty-four eyes were recorded from outpatients in RSDK. 
Inclusion criteria were patients who had a BCVA of 6/6, aged 20-39 years, and was their first visit to the Ophthalmology clinic in RSDK, patients had also been given consent to become research subjects. Patients with ophthalmologic disorders such as infection, glaucoma, amblyopia, or retinal disease were excluded. Subjects were given cycloplegia (tropicamide 1\%) and repeated after 10 minutes. The examination with an autorefractometer (lucid kr or ker refractometer) and repeated 3 times; mean data was collected. Retinoscopy examination with a streak retinoscopy (Welch Allyn) was later completed. Visual examination with subjective refraction utilizing a Snellen chart or finger counting was then recorded. The examination took place in the same room with similar lighting to avoid bias.

Data produced from $\mathrm{RE}$ and $\mathrm{AR}$ is converted to spherical equivalent (SE) and results were compared. (Figure 1)

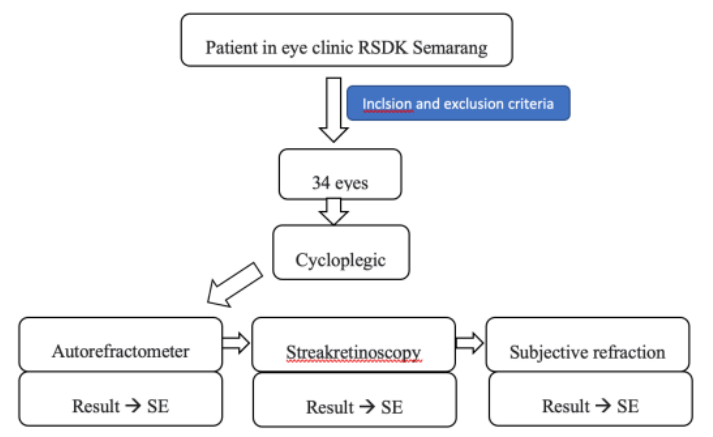

Figure 1. Research schematic

\section{Statistical analysis}

Descriptive statistics included the measurement of means and frequencies. Correlation between RE, AR, and SR was determined using Person's Correlation coefficient. All statistical analyses were performing using SPSS. $\mathrm{p}<0.05$ and $\mathrm{r}>0.8$ is statistically significant with strong correlations.

\section{RESULTS}

This study reviewed 34 eyes (20 right eyes and 14 left eyes) which met the inclusion and exclusion criteria. Based on demographics, the majority of samples were women $(61.8 \%)$ with a mean age of $29.7 \pm 9$, most being an entrepreneur $38 \%$, with optotype vision $64.7 \%$ and finger counting $35.3 \%$. Most of the subjects lived outside of Semarang $61.8 \%$. Diagnosis of the subjects included myopia $44.1 \%$, hypermetropia $14.7 \%$, and astigmatism 41.2\%. (Table 1).

Tabel 1. Demographic Data

\begin{tabular}{|c|c|c|c|}
\hline Demographic Data & Frequency & $\begin{array}{c}\text { Percentage } \\
(\%)\end{array}$ & Mean \\
\hline Ages & & & $29.7 \pm 9$ \\
\hline$<20$ yo & 4 & $11.7 \%$ & \\
\hline $20-30$ yo & 12 & $35.3 \%$ & \\
\hline$>\mathbf{3 0}$ yo & 18 & $52 . .9 \%$ & \\
\hline \multicolumn{4}{|l|}{ Gender } \\
\hline Male & 13 & $38.2 \%$ & \\
\hline Female & 21 & $61.8 \%$ & \\
\hline \multicolumn{4}{|l|}{ Occupation } \\
\hline Laborer & 1 & $2.9 \%$ & \\
\hline Housewife & 9 & $26.5 \%$ & \\
\hline College students & 7 & $20.6 \%$ & \\
\hline Entrepreneur & 13 & $38 \%$ & \\
\hline Students & 2 & $5.8 \%$ & \\
\hline Civil servants & 2 & $5.8 \%$ & \\
\hline \multicolumn{4}{|l|}{ Visual acuity } \\
\hline Optotype & 22 & $64.7 \%$ & \\
\hline Finger counting & 12 & $35.3 \%$ & \\
\hline \multicolumn{4}{|l|}{ Domicile } \\
\hline Semarang & 13 & $38.2 \%$ & \\
\hline Out of town & 21 & $61.8 \%$ & \\
\hline \multicolumn{4}{|l|}{ Diagnosis } \\
\hline Myopia & 15 & $44.1 \%$ & \\
\hline Hyperopia & 5 & $14.7 \%$ & \\
\hline Astigmatism & 14 & $41.2 \%$ & \\
\hline \multicolumn{4}{|l|}{ Side } \\
\hline Right eye & 20 & $58.8 \%$ & \\
\hline Left eye & 14 & $41.2 \%$ & \\
\hline
\end{tabular}

The mean of SE in RE is $4.23 \pm 4.6$ $\mathrm{D}$, the mean of SE in SR is $3.91 \pm 4.6 \mathrm{D}$, and the mean of SE in AR is $4.06 \pm 4.6$. Correlation between SE from RE and SR with p-value $<0.001, \mathrm{r} 0.997$. (Table 2).

Table 2. Correlation between SE from RE, AR and SR

\begin{tabular}{|l|c|c|c|c|}
\hline & Mean \pm SD & $\begin{array}{c}\text { Median (Min - } \\
\text { Max) }\end{array}$ & p value & r \\
\hline Retinoscopy & $4.23 \pm 4.6$ & 6 & $<0.001$ & 0.997 \\
\hline Subjective Refraction & $3.91 \pm 4.6$ & 6 & & \\
\hline & Mean \pm SD & $\begin{array}{c}\text { Median (Min }- \\
\text { Max) }\end{array}$ & p value & r \\
\hline Autorefractometry & $4.06 \pm 4.6$ & 6 & $<0.001$ & 0.995 \\
\hline Subjective Refraction & $3.91 \pm 4.6$ & 6 & & \\
\hline
\end{tabular}

The results from Pearson correlation between RE and RS are statistically significant with strong correlation $(y=-0.137+0.998 x) \quad(r=0.997$ 
( $\mathrm{p}<0.001)$. (Figure 2a). In addition, the correlation between $\mathrm{AR}$ and $\mathrm{SR}$ are statistically significant, as well. $(y=-0.249$ $+0.984 \mathrm{x}),(\mathrm{r}=0.995$ ( $\mathrm{p}<0.001)$. (Figure $2 b)$.

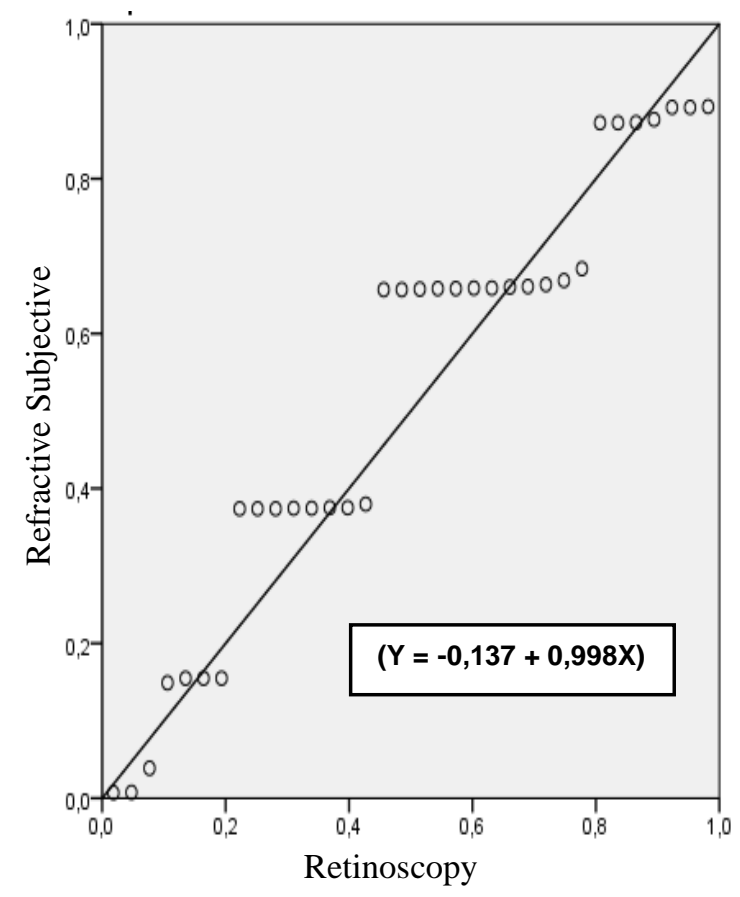

(a)

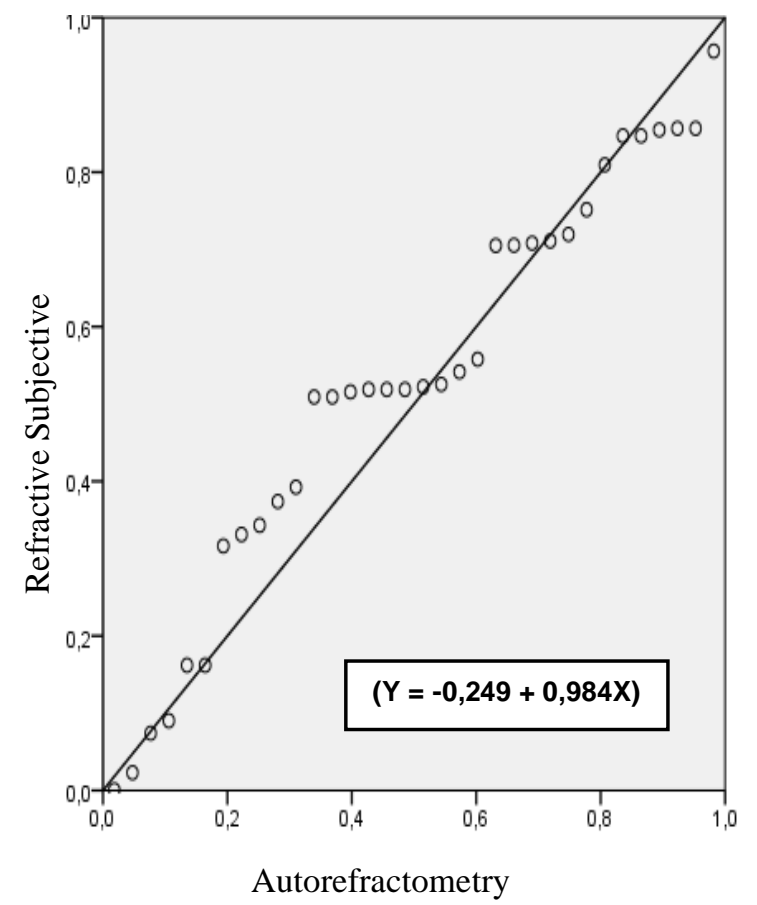

(b)

Figure 2. (a). Scatter plot of Pearson Correlation between RE and SR, (b). Regression between AR and SR

\section{DISCUSSION}

This study reviewed 34 eyes, most of which were women $(61.8 \%)$ with a mean of age of $29.7 \pm 9$. The results are consistent with a previous study from Pliyama which presented 90 patients and were then divided into 2 groups, 45 adults and 45 children. In both groups, refractive errors were found more in women than men. However, another study from 14 regions in Mexico showed different results in 676.856 patients age 6-90 years, men $61.2 \%$ had a higher prevalence than women $58.3 \%$. The difference is due to the location and number of sample. ${ }^{7,8}$

Age range from 20-39 years was selected to reduce the effect of amplitude accommodation. Previous studies have examined refractive errors in school-aged children as the incidence of refractive errors occurs mostly in this age group. However, Hashemi, in his systematic review and meta-analysis reported that refractive errors could occur at any given age. In Dr. Kariadi Hospital, most patient visits are of productive age (20-39 years).

Results showed the most diagnosis is myopia (44.1\%). This is consistent with a study in Mexico that reports myopia as the main cause of refractive errors $24.8 \%$ and occurs in the 10-39 years age group. A study by Puspitasari 2017 in RSUP Adam Malik Medan reports from 64 myopia subjects that received trial and error subjective refraction and objective refraction with streak retinoscopy showed no significant result $\mathrm{p}>0.05 .8,9,10$

This study reports the correlation between SE in RE and AR compared with subjective refraction and showed significant results $\mathrm{p}<0.001$. This would explain that $\mathrm{AR}$ examination is equivalent though not as accurate as RE. This correlates with other studies that show the comparison of $\mathrm{SE}$ in $\mathrm{AR}$ and $\mathrm{SR}$ is statistically significant although AR is not as accurate as RE in all refractive errors including astigmatism. ${ }^{11,12,13}$

Bennet reports no significant value in AR and SR with $p=0.62$ in 120 adult eyes. 
Uras et. al completed a study to estimate the similarities between AR and RE with SR in 192 adolescents without cycloplegia, results show that AR had more negative results and occasionally more positive results compared to subjective refraction (overcorrection). Therefore, streak retinoscopy is more accurate in an experienced ophthalmologist. Prabhakar SK conducted a study to find the correlation of the accommodative effort with the dynamic refraction in emmetropic children, and revealed that the performance of autorefractor was comparable to retinoscopy accuracy. ${ }^{14,15,16}$

Bullimore ma et. al evaluated the accuracy of autorefractometer using 3 different autorefractometer and subjective refraction in diagnosing refractive errors in children. This study involved 117 subjects without cycloplegia, results showed that all 3 autorefractometer tends to overcorrect, especially in myopia patients. Nonetheless, the autorefractometer is accurate with cycloplegia. Tongue et al correlates the accuracy of rma 3000 autorefractometer with conventional retinoscopy. Sixty - nine eyes with a negative spheric lens will be higher in autorefractometer with cycloplegia and lower in a positive spheric lens.

Limitations of this study are the limited numbers of samples and the age range of patients are small. In addition, the samples were not grouped according to their respective refractive errors.

\section{CONCLUSION}

This study shows retinoscopy is superior to autorefractometry. However, autorefractometry is a viable replacement for patients in Dr. Kariadi Hospital Semarang with increasing numbers of outpatient visits.

\section{REFERENCE}

1. Infodatin Pusat data dan informasi kementerian kesehatan RI. Situasi gangguan penglihatan dan kebutaan. 2014. Indonesia
2. Flaxman SR, Bourne RRA, Resnikoff S, et al. Global causes of blindness and distance vision impairment 1990-2020: a systematic review and meta-analysis. Lancet Glob Health. 2017;5(12):e1221- e1234

3. TR Fricke, BA Holden, DA Wilson, G Schlenther, KS Naidoo. Global cost of correcting vision impairment from uncorrected refractive error. World Health Organization. 2012. Australia.

4. Hashemi Hassan, et all. Global and regional estimates of prevalence of refractive errors: Systematic review and meta-analysis. ScienceDirect. 2017. Iran

5. Rumondor.Nandy, Rares. Laya. Hubungan Kelainan Refraksi dengan Prestasi Belajar Anak di SMP Kristen Eben Haezar 2 Manado. Universitas Samratulangi Manado.

6. Retinoscopy Handbook for Clinicians. Retinometri manual for practicing clinicians. New England. Orbis. Page 4-14. 2015

7. Mukash SN, Kayembe DL, Mwanza JC. Agreement between retinoscopy, autorefractometry and subjective refraction for determining refractive errors in Congelese children. Dovepress. Clinical optometri 2021:13 129-136.

8. Paliyama, M. Perbandingan selisih nilai reflaksi subjektif dengan nilai streak retinoskopi dan autorefractometer tanpa sikloplegik pada anak dan dewasa. ETD UGM. 2009. Yogyakarta.

9. Salazar, et all. Refractive errors among children, adolescents, and Adultsattending eye clinics in Mexico. In J Ophtlamology.Volume 10. 2017. Mexico.

10. Elliot, David B. Determination of the refractive correction. Clinical procedure in health eye care. 98-106.

11. Puspitasari. Serly indah. Perbandingan hasil koreksi pemeriksaan subjektif (Trial and error) dengan pemeriksaan objektif (Streak Retinoskopi) tanpa sikloplegik pada penderita miopia. Repository Universitas Sumatera Utara. 2017. Medan.

12. Bennet Jeffrey. Comparison of autorefraction to subjective refraction. American Academy of Optometry. 2009. Mayoclinic health system. Florida

13. Ganger Anita, Saroj Bala, Kaur Inderjit,Kaur Prempa, Satpal. Comparison of Autorefractometer, Retinoscope and Subjective Method in Miopic and Hypermetropic Patients. Internasional Journal of Contemporary Medical Research. 2017. Volume 4. 740-743.

14. Asiedu K, Kyei S, Ampiah EE. Autorefraction, retinoscopy, javal's rule, and Grosvenor's modified javal's rule: the best 
predictor of refractive astigmatism. J Ophthalmol. 2016;2016:3584137

15. Uras R, Belfort R, Hofling-Lima AL, Martins EL. Automatic objective refraction and clinical refraction - a comparative analysis Arq Bras Oftalmol. 2001;64:33-.the general population. Elsevier. 2015. Volume 122. Page 101-109.

16. Prabhakar SK. Study on accommodation by autorefraction and dynamic refraction in children. J Optom. 2014;7:193- 202. 